\title{
PENGALAMAN PASIEN GANGGUAN JIWA KETIKA DIBERIKAN TERAPI GUIDED IMAGERY
}

\author{
Arum Pratiwi $^{1^{*}}$, Eka Mutya ${ }^{2}$, Selvya Hesti Andriyani ${ }^{2}$ \\ ${ }^{1}$ Departemen Keperawatan Jiwa dan Manajemen, Program Studi Keperawatan, Fakultas Ilmu Kesehatan, \\ Universitas Muhammadiyah Surakarta \\ ${ }^{2}$ Program Studi Keperawatan, Fakultas Ilmu Kesehatan, Universitas Muhammadiyah Surakarta \\ *Email: Arum.Pratiwi@ums.ac.id
}

\begin{abstract}
ABSTRAK
Pemahaman terkait pengalaman pasien gangguan jiwa setelah diberikan terapi guided imagery merupakan hal penting karena guided imagery adalah salah satu terpai modalitas yang dianjurkan untuk digunakan dalam membantu mengubah perilaku pasien gangguan jiwa yang maladptif menajdi adaptif. Penelitian ini bertujuan untuk menggali informasi terkait pengalaman pasien gangguan jiwa ketika guided imagery diberikan. Penelitian ini merupakan penelitian qualitatif dengan menggunakan metode narrative inquiry. Penelitian ini dilakukan di Rumah Sakit Jiwa Surakarta selama 2 bulan. Total sampel berjumlah 16 pasien gangguan jiwa yang belum pernah mendapatkan terapi guided imagery dan sample diambil menggunakan teknik non-probability sampling. Data diambil menggunakan wawancara mendalam dan observasi tehadap responden. Analisis tematik adalah jenis analisis yang digunakan untuk menganalisa data tersebut. Hasil dari identifikasi tema ditemukan 2 tema utama berkaitan dengan pengalaman pasien gangguan jiwa ketika diberikan terapi guided imagery. Tema tersebut ialah resiko kekerasan terhadap orang lain dan yang kedua ialah perasaan nyaman.
\end{abstract}

Kata kunci: Pengalaman, gangguan jiwa, guided imagery

\section{THE EXPERIENCE OF MENTAL ILLNESS PATIENT USING GUIDED IMAGERY RELAXATION}

\begin{abstract}
Understanding the experience of mental illness patient after being given guided imagery is important because guided imagery is one of suggested modality therapy that used to change the behavior of mental patients who had maladaptive behavior to be adaptive. This research aim is to explore information related to experiences of mental patients when relaxation guide imagery is performed. The study was a qualitative method with narrative inquiry method. The researcher conducted the study at Surakarta mental hospital for two months. The samples werel6 mental illness patient who has never received guided imagery therapy before and was taken by nonprobability sampling. The data were taken by in-depth interview and observation toward the respondent. Thematic analysis was used to analyze the data. The results of the theme identification found two main themes related to the experience of patients with mental disorders when given guided imagery therapy. Those themes are Risk for other-directed Violence and Feeling Convenience.
\end{abstract}

Keywords: Experience, mental illness, guided imagery

\section{PENDAHULUAN}

Individu merupakan seseorang yang memiliki ciri khas dan kepribadian masing - masing, sehingga individu memiliki koping mekanisme yang berbeda - beda satu sama lain. Koping mekanisme ini berguna agar individu dapat beradaptasi dengan kondisi yang ada. Diharapkan dengan memiliki koping mekanisme yang baik individu dapat mencapai kondisi sehat fisik maupun mental. Konsep sehat menurut Sutejo (2017) merupakan keadaan yang sempurna baik fisik, mental maupun sosial, tidak hanya terbebas dari penyakit atau kelemahan serta kecacatan, sehingga konsep sehat bukan hanya bebas dari penyakit atau kecacatan 
namun juga memiliki kondisi sehat jiwa dan mampu bersosialisasi dengan orang lain.

Menurut Ardani (2013) bahwa kesehatan Jiwa yaitu kondisi dimana seorang individu dapat berkembang secara fisik, mental, spiritual, dan sosial sehingga individu tersebut menyadari kemampuan sendiri, dapat mengatasi tekanan, dapat bekerja secara produktif, dan mampu memberikan kontribusi untuk komunitasnya, sedangkan seorang dengan gangguan jiwa memiliki gangguan dalam pikiran, perilaku, dan perasaan yang ditandai dalam bentuk sekumpulan gejala atau perubahan perilaku yang bermakna, serta dapat menimbulkan permasalahan dan hambatan dalam menjalankan fungsi orang sebagai manusia. Menurut Rinawati (2016) seseorang dapat menderita gangguan jiwa disebabkan dari beberapa faktor yang mempengaruhi misalnya sosial ekonomi, tingkat pendidikan, statuts pekembangan, pengalaman dan konflik yang ada dalam kehidupannya. Kondisi perkembangan zaman seperti sekarang ini memungkinkan banyak orang terkena penyakit jiwa karena banyaknya penekanan dalam kehidupan.

Menurut data World Health Organization (2016) terdapat sekitar 35 juta orang terkena depresi, 60 juta orang terkena skizofrenia dan 47,5 juta terkena dimensia yang terjadi pada tahun 2016. Gangguan jiwa di Tanah Air masih cukup besar. Kejadian gangguan mental emosional yang ditunjukkan dengan gejala-gejala depresi dan kecemasan adalah sebesar 6\% untuk usia 15 tahun ke atas atau sekitar 14 juta orang. Sedangkan, prevalensi gangguan jiwa berat, seperti schizophrenia adalah 1,7 per 1000 penduduk atau sekitar 400.000 orang (Dinas Kesehatan, 2013).

Berdasarkan data yang diperoleh Dinas Kesehatan Jawa Tengah (2016) jumlah kunjungan penderita gangguan jiwa ke rumah sakit jiwa tahun 2016 sebanyak 413.612. Berdasarkan data rekam medis Rumah Sakit Jiwa Daerah Surakarta (2018) jumlah kunjungan pasien di mulai dari tahun 2012 sampai 2017 tercatat pada tahun 2012 sebanyak 5.906 kali kunjungan, Sementara pada 2013 menjadi 3.190 kali kunjungan, kemudian 2014 menjadi 3.139 kali kunjungan, sedangkan pada tahun 2015 yang mencapai 2.817 kali kunjungan, tahun 2016 mengalami peningkatan dari tahun sebelumnya yaitu terdapat 2.993 kali kunjungan, padatahun 2017 angka kunjungan rumah sakit jiwa mencapai 2.815 kali kunjungan. Keadaan jumlah kunjungan pasien gangguan jiwa yang tidak sedikit ini membutuhkan terapi yang tepat agar dapat memberikan tindakan terbaik untuk kesembuhan pasien, sehingga dapat dipilih terapi yang ada dalam keperawatan untuk menangani gangguan jiwa antara lain terapi modalitas, terapi komplementer dan terapi farmakologi (Nasir, 2011).

Terapi modalitas merupakan terapi yang memfokuskan cara pendekatan dengan pasien gangguan jiwa yang bertujuan untuk mengubah prilaku pasien gangguan jiwa yang tadinya berprilaku maladaptif menjadi adaptif (Sutejo,2017). Salah satu terapi modalitas yang dianjurkan untuk menurunkan depresi dan kecemasan pasien gangguan jiwa dapat dilakukan dengan pemberian relaksasi guide imagery. Menurut Susana (2012) Relaksasi guided imagery merupakan terapi keperawatan yang dilakukan dengan cara mengajak pasien untuk membayangkan hal-hal yang membahagiakan dalam hidupnya sehingga menimbulkan rasa senang dan sedikit melupakan beban pikiran yang dirasakan.

Penelitian yang dilakukan oleh Hudaya (2015) teknik guided imagery dapat mengurangi kecemasan diperoleh $81 \%$ subjek penelitian mengalami penurunan tingkat kecemasan dan $19 \%$ subjek penelitian tingkat kecemasannya tetap. Berdasarkan studi pendahuluan yang dilakukan pada tanggal 21 Mei 2018 didapatkan data kunjungan dalam 1 tahun belakangan di Rumah Sakit Jiwa Daerah Surakarta sebanyak 2815 kunjungan. Fenomena yang ada bahwa pasien yang mengalami cemas dan amuk pada awalnya akan diajak komunikasi terapeutik dan diberikan terapi farmakologi untuk penenang, selanjutnya dilakukan restrain atau pengikatan pada bagian ekstremitas pasien. Pemeberian restarain memiliki resiko cidera fisiologis dan psikologis apabila tidak dilakukan dengan benar. 
Terapi yang bisa digunakan selain restrain dan terapi farmakologi juga dapat dilakukan terapi modalitas yang bertujuan sebagai pendamping dari terapi farmakologi dan restrain tersebut. Terapi modalitas yang dapat dipilih yaitu terapi guided imagery. Guided imagery dilakukan dengan tujuan memberikan rasa rileks, mengurangi sakit, stres dan cemas pada pasien (Nguyen, 2012). Berdasarkan keadaan dilapangan tidak ada jadwal rutin untuk dilakukannya terapi guided imagery sehingga tidak diketahui respon dan kondisi yang ditunjukan setelah pemberian terapi guided imagery.

Berdasarkan fenomena yang ada, maka peneliti tertarik untuk melakukan penelitian terkait pengalaman pasien sebelum dan sesudah dilakukan terapi guided imagery dengan menggunakan jenis penelitian kualitatif. Tujuan dari penelitian ini adalah untuk menggali informasi terkait pengalaman pasien gangguan jiwa ketika dilakukan tindakan relaksasi guide imagery. Dengan demikian, hasil eksplorasi secara mendalam tentang pengalaman pasien gangguan jiwa tersebut dapat digunakan untuk membantu perawat dalam memberikan terapi modalitas dalam menangani pasien gangguan jiwa serta dapat memahami kondisi pesien gangguan jiwa.

\section{METODE}

Penelitian ini menggunakan jenis penelitian kualitatif dengan desain narative inqury. Menurut penelitian Pratiwi (2016) penelitian kualitatif jumlah sample penelitian mencapai saturasi 10orang partisipan sedangkan pada penelitian ini peneliti mengambil 16 orang pasien gangguan jiwa yang belum pernah mendapatkan terapi guided imagery. Desain penelitian narative inqury itu sendiri yaitu penelitian yang mengkaji cerita yang disampaikan oleh seseorang dan bersamasama mengkonstruksi setelahnya menganalisis dalam bentuk narasi sebuah cerita. Penelitian ini menitik beratkan pada pengalaman dalam cerita kehidupan atau sejarah kehidupan seseorang (Setyosari, 2013).

Pengambilan data menggunakan Non Probability sampling dengan mengambil sample proporsi. Instrumen penelitian ini menggunakan pedoman wawancara dengan metode indepth interview, observasi responden, alat tulis, recorder berupa handphone guna pendokumentasian. Analisis data menggunakan analisis tematik. Uji validitas menggunakan triansgulasi metode.

\section{HASIL}

Hasil dari penelitian didapatkan gambaran karakteristik resonden berjumlah 16 orang yang kebanyakan berjenis kelamin laki-laki dengan jumlah sebelah orang dan lima orang berjenis kelamin perempuan. Rentang usia 23-52 tahun. Tingkat pendidikan bervariasi dari SD sampai SMA, tapi sebagian besar mengenyam pendidikan sampai Sekolah Menengah Atas. Partisipan baru pertama kali mendapat terapi guided imagery. Hasil dari identifikasi tema didapati 2 tema utama yang berkaitan dengan pengalaman pasien ganggua jiwa ketika diberikan terapi guided imagery, yaitu: pertama resiko kekerasan terhadap orang lain dan yang kedua ialah perasaan nyaman.

\section{PEMBAHASAN}

Tema yang pertama, berkaitan dengan resiko kekerasan terhadap orang lain, ditunjukan melalui perkataan pasien terkait beberapa perilaku yang biasa dilakukan oleh pasien gangguan jiwa ketika adanya peningkatan status emosional pasien. Yang pertama ialah faktor sosial mengakibatkan marah partisipan menceritakan penyebab terjadinya marah, didapati 12 partisipan mengatakan bahwa marahnya dipengaruhi oleh masalah dengan orang disekitarnya seperti orang tua, saudara, teman, pasangan hidup dan tetangga.

$$
\begin{array}{r}
\text { “...masalah dengan orang lain” }(\mathbf{R}) \\
\text { “...masalah dengan kakak saya” }(\mathbf{R 2}) \\
\text { “...yang bikin saya kesal itu teman saya" } \\
(\mathbf{R 3}) \\
\text { “...biasanya kakak saya” }(\mathbf{R 4}) \\
\text { “...ada masalah sama tetangga” }(\mathbf{R 7}) \\
\text { “..teman saya menjebak saya” }(\mathbf{R 8})
\end{array}
$$

“...dikatain gila sama tetangga-tetangga saya" 
“...bapak saya engga boleh keluar” (R10)

$$
\text { “...bapak saya” (R11) }
$$

“...yang bikin saya marah itu kakak saya"

(R12)

“...yang bikin saya kesal itu istri saya mba"

(R14)

$$
\text { “...sama mbah saya” (R16) }
$$

Hasil penelitian yang dilakukan oleh Husni (2014) ini menunjukan penyebab utama terjadinya emosi marah adalah perasaan terluka. sebagian responden memiliki faktor penyebab kemarahan adalah perasaan tidak mengenakan yang terjadi ketika seseorang merasa tidak senang dengan prilaku orang lain terhadap dirinya, dimana seseorang mengalami kejadian seperti dikhinati, dihina, diremehkan, difitnah dan disakiti. Perasaan emosi yang disampaikan oleh partisipan dicerminkan dengan reaksi nonverbal dimana ekspresi wajah partisipan berubah dengan mengerutkan kening dan tegang saat bercerita.

Kedua yaitu didapati gejala gangguan jiwa yang mengakibatkan marah. Gangguan kejiwaan meliputi gangguan pada emosi, proses pikir, perilaku, dan presepsi yang menimbulkan penderitaan pada individu dan atau hambatan dalam melaksanakan peran sosial, kerja dan fisik individu (Sutejo, 2017). Pada hasil wawancara yang dilakukan bersama partisipan didapati empat partisipan marah dikarenakan faktor gangguan jiwa seperti adanya bisikan, gangguan presepsi dan kebingungan.

“...Ada bisikan-bisikan yang jelek-jelek"

(R5)

$$
\text { “...karna saya sakit perut” }
$$

“...saya kecapean kerja, kerja terus 2 tahun"

(R13)

“...Saya bingung kaya orang linglung” (R15)

Menurut Yosep (2014) adanya gangguan emosi yang terjadi pada pasien penderita gangguan jiwa berupa emosi labil, sehingga emosi dapat beruah-ubah dengan cepat. Responden merasa terganggu dengan adanya gangguan pada kejiwaannya seperti partisipan yang merasa terganggu dengan adanya gangguan presepsi mulai dari suara maupun rasa nyeri, sehingga pasien meluapkannya dengan marah.

Ketiga yaitu memukul saat marah. Tercatat sepuluh partisipan menyatakan bahwa melakukan prilaku kekerasan berupa pemukulan terhadap orang terdekat maupun orang-orang yang tidak dikenalnya, dalam proses wawancara didapati partisipan terlihat bersemangat membahas tentang prilaku kekerasan yang dilakukannya.

"...mukul tembok, kadang mukul ibu saya"

$$
\text { “...mukul anak saya” (R5) }
$$

“...bapak saya pukul kepalanya” (R6)

"...saya pukulin aja dia pake balok kayu"

“..., saya samperin terus saya pukul mukanya"(R8)

"...Kalau marah saya pukul tetanga saya"

(R9)

“...mukul kaca rumah dan tv saya banting"

(R10)

“...saya suka marah-marah mukul-mukul"

(R13)

“...saya pukul istri saya" (R1)

“...Sampai saya mukul ade saya" (R15)

Perilaku kekerasan telah dilakukan oleh penderita gangguan jiwa terhadap orang lain termasuk para keluarga, profesional perawat dan masyarakat umum (Subu, Holmes, \& Elliot, 2016). Prilaku kekerasaan yang biasa dilakukan oleh penerita gangguan jiwa berupa kekerasan fisik yaitu pemukulan dengan sasaran orang terdekat maupun orang-orang yang tidak dikenalnya yang melintas di depannya. 
Keempat yaitu membanting barang dan membentak saat marah. Respon maladaptif dengan melakukan tindakan berupa kekerasan verbal dan non verbal dalam meluapkan marahnya dialami enam partisipan. Mulai dari membentak, membanting gelas dan tv. Selama wawancara partisipan sesekali memperagakan bagaimana dirinya dalam membanting barang

“...teriak-teriak dan bentak-bentak orang"

“...saya bentak-bentak teman saya” (R3) “...banting gelas" $(\mathbf{R} 1)$

“...bentak-bentak kakak” (R12)

$$
\text { “...banting gelas" }(\mathbf{R} 16)
$$

Keliat (2009) lebih jelas menyatakan bahwa perilaku kekerasan pasien gangguan jiwa mengacu pada perilaku verbal maupun non verbal, dimana perilaku verbal meliputi menyakiti orang lain yang berupa umpatan, celaan atau makian, fitnahan atau ancaman melalui kata-kata. Sedangkan perilaku non verbal adalah perlaku berbentuk memukul, menendang, mencubit dengan kasar, mengancam orang lain menggunakan senjata, menyerang orang lain dan membanting barang. Penelitian ini menunjukkan bahwa sebagian besar responden memiliki perilaku kekerasan berupa memukul atau menyakiti orang lain sedangkan sebagian kecil melakukan tidakan verbal dan nonverbal.

Disisi lain, untuk tema yang kedua yaitu perasaan nyaman yang didapati pasien setelah mendapatkan terapi guided imagery. Perasaan nyaman pasien itu sendiri diekspresikan pasien itu sendiri melalui perkataan pasien terkait perasaan nyaman yang mereka rasakan secara fisik maupun psikologis setelah terapi diberikan.

Pertama yaitu guided imagery menenangkan pikiran. Terapi guided imagery dilakukan dengan cara membayangkan sesuatu tempat yang disukai bagi partisipan, seperti kegiatan apa, dimana dengan siapa. Cara ini memungkinkan partispan dapat menenangkan pikiran dengan hal-hal yang membuat pasien nyaman.

“...nyaman banget, Tidak deg-degan, tapi lebih nyaman, lebih rileks" (R1)

“...lebih plong dan lepas, lega permasalahan ilang. Mengurangi pikiran" (R2)

“...Jadi anget, nyaman. ayem (tenang) tadinya saya deg-degan" (R4)

“...Plong. Lemesnya jadi kaya santai. Engga ada rasa takut" (R5)

“...perasaan hanyut, Rasanya nyaman merasa hangat" (R6)

“...nyaman mba, pengen tidur" (R7)

"Perasaan adem, ayem seneng dan plong mba" (R8)

“...bikin hati saya adem, nyaman sejuk, rileks, plong, ayem, tentrem" (R9)

“...Lebih rileks dan plong, lebih tenang, engga ada beban, engga ngerasa

ketakutan dan nderedeg (deg-degan)"

(R11)

$$
\text { “...Rasanya lega" (R14) }
$$

“...sejuk sampai kehati lebih santai, nafasnya juga enak teratur" (R15)

“...plong, bebas berkurang beban"

(R16)

Penlitian yang dilakukan Hudaya (2015) tingkat kecemasan pada pasien skizofrenia di Rumah Sakit Jiwa Daerah Surakarta bahwa ada penurunan kecemasan pada pasien gangguan jiwa setelah diberikan terapi guided imagery yang ditunjukan dengan perubahan presentasi tingkat kecemasan pasien gangguan jiwa. Kecemasan pada pasien penderita skizofrenia dapat berkurang dengan menggunakan terapi musik terbimbing untuk mengalihkan rasa cemasnya (Pratiwi, 2015). Sejalan dengan penelitian ini sebagaian besar partisipan memberikan keterangan bahwa adanya 
perasaan plong, riles, nyaman dan tidak degdegan. Dibuktikan dengan reaksi yang raptisipan berikan saat melakukan wawancara dimana reaksi partisipan tidak lagi menampakkan raut wajah tegang.

Kedua ialah guided imagery menyenangkan. Perasaan senang saat proses terapi guided imagery telah dilakukan juga diungkapkan oleh partisipan. Perasaan senang partisipan dikarenakan mengingat kembali masa lalu yang pernah dialami partisipan bersama dengan orang terdekatnya serta menghilangkan rasa bosan yang dirasakan partisipan.

$$
\begin{array}{r}
\text { “...Rasanya seneng” (R3) } \\
\text { “...senang, bahagia.” (R5) } \\
\text { “...senang, engga sumpek” (R10) } \\
\text { “...bahagia” (R12) } \\
\text { “...seneng,” (R13) } \\
\text { “...senang gembira” (R15) } \\
\text { “...senang, bahagia, happy” (R16) }
\end{array}
$$

Pada saat berlangsungnya terapi guided imagery partisipan nampak senang ditandai dengan adanya senyuman kecil yang didapat pada ujung bibir partisipan dan ditunjang dengan keterangan mengenai kegembiraannya memvisualisasikan pengalaman yang menyenangkan. Beberapa partisipan menuturkan bahwa senang berpergian ketempat yang memiliki pemandangan bagus seperti pegunungan hijau dan jalan-jalan bersama sanak saudaranya sehingga dengan membayangkan hal yang membuat partisipan senang dapat mengalihkan perhatian dari hal yang tidak menyenangkan. Sesuai dengan penelitian yang dilakukan oleh Ayuningtiyas (2017) mengatakan bahwa terapi guided imagery dapat memberikan rasa senang dan menghilangkan rasa sedih dengan cara mengalihkan perhatian partisipan.

Ketiga yaitu Guided imagery memberikan efek merilekskan badan. Terapi guided imagery dilakukan dengan posisi berbaring setelahnya pasien dipandu untuk melakukan tarik nafas dalam serta partisipan didorong menuju alam bawah sadarnya untuk mengenang kejadian yang menyenangkan dalam hidupnya sehingga dapat menurunkan rasa cemas dan kekakuan pada otot. Menurut Sodiqon (2014) Cara yang dapat ditempuh untuk menghilangkan cemas yaitu dengan melakukan teknik relaksasi dengan cara duduk atau berbaring. Lakukan teknik pernafasan, usahakanlah menenentukan posisi nyaman.

“...lebih enak badan" $(\mathbf{R 1})$

“...enak terhiburan” (R3)

“...enteng, seger, pokoknya yang apik-apik"

“...enak pikirannya agak enteng” (R12)

“...badan udah kendor” (R13)

“...Ya enak" (R14)

Terapi guided imagery merupakan terapi pikiran dan tubuh, setiap masalah kesehatan yang berhubungan dengan stres, termasuk tinggitekanan darah, nyeri yang terkait dengan ketegangan otot, insomnia, dan kecemasan atau depresi, dapat diatasi melalui terapi guided imagery (Prabu, 2015). Keterangan yang disampaikan oleh partisipan yang mengatakan bahwa badannya kendor, enteng dan seger menunjukan bahwa adanya kerileksan otot pada tubuh partisipan.

Keempat yaitu Guided imagery menghilangkan marah. Faktor sosial dan gangguan jiwa yang di rasakan partisipan mengakibatkan partisipan menunjukan respon emosi dan marahnya dengan cara memukul orang, membanting barang dan berteriak-teriak. Wawancara dilakukan dengan partisipan yang menunjukan respon marah dengan mengerutkan dahi serta mata melotot.

$$
\begin{aligned}
& \text { “...lebih enak badan” (R1) } \\
& \text { “...enak terhiburan” (R3) }
\end{aligned}
$$

“...enteng, seger, pokoknya yang apik-apik” 
“...enak pikirannya agak enteng” (R12)

“...badan udah kendor” (R13)

$$
\text { “...Ya enak" (R14) }
$$

Setelah dilakukan terapi guided imagery pasien memberikan keterangan bahwa terapi guided imagery mebuatnya terhibur dan dapat mengontrol emosinya yang sebelumnya meluap-luap. Terapi guided imagery yang dilakukan dengan diawali dengan tarik nafas dalam dan di lanjutkan dengan mengatur nafas secara teratur dapat mengurangi perasaan marah partisipan. Mengatur nafas pada terapi guided imagery dalam waktu 60 detik dapat mengurangi perasaan marah serta perasaan-perasaan negatif lainnya (ChadFriedman, Talaei-Khoei, Ring, \& Ana-Maria Vranceanu, 2017). Menurut Case Laura (2018) Terapi guided imagery selain dapat mengurangi emosi juga dapat bermanfaat untuk perubahan suasana hati depresi dan kelelahan serta peningkatan kualitas Physical dan mental hidup klien. Data pendukung bahwa terapi guided imagery dapat mengurangi marah diutarakan oleh partisipan dengan tidak mengerutkan dahi dan mata pasrtisipan tidak melotot.

\section{SIMPULAN DAN SARAN \\ Simpulan}

Karakteristik pasien skizofrenia di Rumah Sakit Jiwa Daerah Surakarta sebagian besar berjenis kelamin laki-laki, rata-rata berusia 34 tahun dan memiliki tingat pendidikan sekolah menengah atas atau sekolah menengah kejuruan. Pengalaman penderitagangguan jiwa sebelum dan sesudahmendapatkan terapi guided imagery menghasilkan dua temuan tema utama,yaitu esiko kekerasan terhadap orang lain dan yang kedua ialah perasaan nyaman.

\section{Saran}

Bagi Institusi Pendidikan hasil penelitian ini menguatkan teori-teori tentang pemberian modalitas terapi dalam penurunan tingkat kecemasan dan perilaku agresif pada pasien gangguan jiwa khususnya pasien skizofrenia. Bagi Petugas Rumah Sakit perawat dan manajemen rumah sakit diharapkan mengembangkan metode-metode terapi modalitas lainnya untuk meningkatkan perawatan pasien gangguan jiwa, terutama untuk menurunkan tingkat agresifitas pasien gangguan jiwa. Bagi Peneliti Selanjutnya peneliti selanjutnya dapat melakukan penelitian dengan menggunakan metodemetode modalitas terapi lainnya, sehingga diketahui metode terapi apakah yang paling efektif dan efisien dalam memperbaiki perasaan pasien khususnya dalam menurunkan tingkat kecemasan dan agresifitas pasien gangguan jiwa.

\section{DAFTAR PUSTAKA}

Ardani, \& Ardi, T. (2013). Catatan Ilmu Kedokteran Jiwa. Bandung: CV Karya Putra Darwati.

Ayuningtyas, W. R. (2018). Pengalaman Penderita Rheumatoid Arthritis Ketika Mendapatkan Terapi dengan pendekatan Psikosial: Guided Imagery Di Komunitas. Universitas Muhammadiyah Surakarta.

Candra, I. W., Harini, I. G. A., \& Sumirta, I. N. (2017). Psikologi Landasan Keilmuan Praktik Keperawatan Jiwa (1st ed.). Yogyakarta: Penerbit Andi.

Case, L. K., Jackson, P., Kinkel, R., \& Mills, P. J. (2018). Guided Imagery Improves Mood, Fatigue, and Quality of Life in Individuals With Multiple Sclerosis: An Exploratory Efficacy Trial of Healing Light Guided Imagery. Journal of Evidence-Based Integrative Medicine, 23. Retrieved from https://www.ncbi.nlm.nih.gov/pmc/arti cles/PMC5871039/

Chad-Friedman, E., Talaei-Khoei, M., Ring, D., \& Ana-Maria Vranceanu. (2017). First Use of a Brief 60-second Mindfulness Exercise in an Orthopedic Surgical Practice; Results from a Pilot Study. Arch Bone Jt Surg, 5, no 6. Retrieved from https://www.ncbi.nlm.nih.gov/pmc/arti cles/PMC5736889/

Dinas Kesehatan Provinsi Jawa Tengah. (2016). Profil Kesehatan Jawa Tengah. Retrieved April 24, 2018, from http://www.depkes.go.id/resources/do wnload/profil/PROFIL_KES_PROVI NSI 2016/13 Jateng 2016.pdf.

Dinas Kesehatan Provinsi Jawa Tengah. (2013). Riset Kesehatan Dasar: Definisi gangguan jiwa. Retrieved 
April 28, 2018, from

https://www.google.com/search?q=risk esda+gangguan+jiwa\&ie $=u t f-$

8\&oe=utf-8\&client=firefox-b-ab

Handayani, L., Rahmadani, A., Saufi, A., Masyarakat, F. K., Dahlan, U. A., Soepomo, J. P., \& Yogyakarta, K. (2015). Faktor Risiko Kejadian Skizofrenia Di Rumah Sakit Jiwa Grahasia Daerah Istimewa Yogyakarta (DIY). Humanitas, 13(2), 135-148.

Jannah, M., Yacob, F., \& Julianto. (2017). Rentang Kehidupn Manusia (Life Span Deveopment ) dalam Islam. Aceh, 3(1), 97-114.

Keliat, B. A., \& Akemat. (2009). Model Praktik Keperawatan Profesional Jiwa. Jakarta: EGC.

Mubarta, A. F., Husin, A. N., \& Arifin, S. (2013). Gambaran Distribusi Gangguan Jiwa Di Wilayah Banjarmasin dan Banjarbaru. Berkala Kedokteran, Vol.9 No.

Muhammad I H, H. (2015). Pengaruh Terapi Guided Imagery terhadap Tingkat Kecemasan pada Pasien Skizofrenia di RSJD Surakarta. Universitas Muhammadiyah Surakarta.

Nasir, A., \& Muhith, A. (2011). Dasar-dasar Keperawatan Jiwa Pengantar dan Teori. Jakarta: Salemba Medika.

Nguyen, T. T.-N. (2012). Utilization of Guided Imagery within the Four Phases of Adlerian Therapy. Adlerian Counseling and Psychotherapy.

Fajar, R., \& Alimansur, M. (2016). Analisa Faktor-faktor Gangguan Jiwa Menggunakan Model Pendekatan adaptasi Stres Stuart. Jurnal Ilmu Kesehatan, (41), 34-38.

Husni, D., \& Fitriyani, E. (2014). Perasaan Terluka Membuat Marah. Jurnal Psikologi, 10(2).

Prabu, P. K., \& Subhash, J. (2015). Guided Imagery Therapy, 4(5), 56-58. https://doi.org/10.9790/195904535658

Pratiwi, A., \& Dewi, E. (2016). Cognitive Therapy: A Reality Orientation Model For Mental Reality Orientation Model For Mental Disorder Patients Who Experienced Auditory Hallucinations
(Orientasi Realita pada Pasien Gangguan Jiwa yang Mengalami Halusinasi Dengar). Indonesia Nursing Journal of Education and Clinic (INJEC), 1, no(September 2016), 8289.

https://doi.org/10.24990/injec.v1i1.88

Pratiwi, A., \& Sudaryanto, A. (2015). Acceptance Of Music Stimulation Therapy For Auditory ( Tingkat Penerimaan Terapi Stimulasi Suara pada Pasien Halusinasi Dengar ). Indonesia Nursing Journal of Education and Clinic (INJEC), vol.2, no, 97-102. Retrieved from http://dx.doi.org/10.24990/injec.v2i1.1 7

Shodiqoh, E. R., \& Syahrul, F. (2014). Perbedaan tingkat kecemasan dalam menghadapi persalinan antara primigravida dan multigravida. Jurnal Berkala Epidemiologi, 2, no 1, 141150.

Subu, M. A., Holmes, D., \& Elliot, J. (2016). Stigmatisasi dan Perilaku Kekerasan pada Orang Dengan Gangguan Jiwa (ODGJ) di Indonesia. Jurnal Keperawatan Indonesia, 19(3), 191199.

Susana, Sukma A dan Sri H. 2012. Terapi Modalitas Keperawatan Kesehatan Jiwa. Jakarta: EGC

Sujarwo, \& Livana PH. (2017). Gambaran Dampak Tindakan Restrain Pasien Gangguan Jiwa. Jurnal Ilmiah Permas, Volume 7(No 2), 37-44.

Sutejo. (2017). Keperawatan Kesehatan Jiwa. Yogyakarta: Pustaka Baru Perss.

Wahyudi, A., \& Fibriana, A. I. (2016). Faktor Resiko Terjadinya Skizofrenia ( Studi Kasus di Wilayah Kerja Puskesmas Pati II). Public Health Perspective Journal, 1(1), 1-12.

Yosep, I., \& Sutini, T. (2014). Buku Ajar Keperawatan Jiwa. Bandung: Refika Bandung Aditama. 